SoIFNTISTS (2) (with experience in either of the following fields: genetics and/or biochemistry, tumour biology and/or immunology, and preferably some experience in general virology) for research on tumour viruses and related topics-The Honorary Director, Prof. M. G. P. Stoker, M.R.C.
Experimental Virus Research Unit, Institute of Virology, The University,
Glasgow.

TEOHNIOIAN/JUNIOR TECHNIOAL OFFICER (preferably with experience in microbiology or tissue culture techniques) at Pollards Wood Research Station, Chalfont St. Giles, to assist in molecular biological research-The quoting Ref. $301 / \mathrm{B} / 259$.

ZoologisTs (M.Sc. or Ph.D., with research experience and preferably some knowledge of histology and histochemistry) to participate in experimental multi-disciplinary programmes of basic research in the fleld of food additive toxicology-The Director, British Industrial Bion,

\section{REPORTS and other PUBLICATIONS}

\section{(not included in the monthly Books Supplement)}

\section{Great Britain and Ireland}

University of Birmingham Appointments Board. Annual Report 1965.

Pp. 8. (Birmingham: The University, 1966.) year ending December 31, 1965. Pp. 174. (London: The British Iron and Education in 1965: Being a Report of the Department of Education and Science. Pp. 152. (Ćmnd. 2938.) (London: H.M. Stationery Office, 1966.)

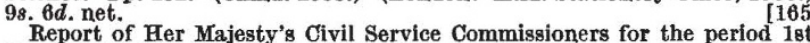
January to 31st December 1965. (99th Report.) Pp, v+34. (London: H.M. Stationery Office, 1966.) 5s. net. The Physics Teachers Handbook. Edited by L. A. Redman. Pp. 232.
(Fairhaven, Lytham St. Annes: Spectrum Books, Ltd., 1966.) 158. net. [165 (Fairhaven, Lytham St. Annes: Spectrum Books, Ltd., 1966.) 158. net. [165 Annual Report of the Oundle School Natural History Society, 1965.
Pp.iii + 107. (Oundle, Peterborough: Oundle School Natural History Society, Pp.iii +107. (Oundle, Peterborough: Oundle School Natural History Society,

Educational Productions, Ltd., Filmstrip C6135: Life on the Sea Shore. 35 frames. Filmstrip Notes (revised edition). Pp. 16. (London and East
Ardsley, Wakefield: Educational Productions, Ltd., 1966.) Ardsley, Wakefield: Educational Productions, Ltd., 1966.)
National Institute of Industrial Psychology. Report No. 19: AudioNational Institute of Industrial Psychology. Report No. 19: Audio-
Typing $-a$ Study of the Work in One Large Organization. By Caroline Warne. Pp. 32. (London: National Institute of Industrial Psychology, 1966.) 6s. 6d. Doctors and Nurses-An Interim Report on a National Book League Investigation. By Dr. J. E. Morpurgo. Pp. 41. 8s. 6d. The Planning and Organization of Medical Book and Journal Services in Regional Hospitals-a National Book League Guide for Librarians. Pp. 34. 3s. 6d. (London The Nuffield Provincial Hospitals Trust, 1966.)

The Nuffield Foundation Science Teaching Project-Progress Report worth, Middx. 27. (London: Longmans, Gre

British Welding Research Association-Twenty-First Annual Report 1965 Pp. 54, (London: British Welding Research Association, 1966) [175 Don't Smoke. By R. W. Kind and John Leedham. (Discovery Pro-
grammes.) Pp. 32. (London: Longmans, Green and Co., Ltd., 1966.)
38. [175 $^{2}$

European Brewery Convention. Report of the Barley Committee-Trials 1964. Pp. 173. (London: The Institute of Brewing, 1966.) [175 Ministry of Technology: National Engineering Laboratory. Heat Biblio-
graphy 1965. Pp. vili + 478, (Edinburgh and London: H.M. Stationery graphy 1965. Pp. vili +478. (Edinburgh and London: H.M. Stationery Office, 1966.) Mathematical and Physical Sclences. No. 1104, Vol. 259 (19 May 1966): Rotational Analysis of the $2600 \AA$ Absorption System of Benzene. By J. H.
Callomon, T. M. Dunn and T. M. Mills. Pp. 499-532+ plates 7-10. 188. 6 . 2.75 dollars. No. 1105, Vol. 259 (19 May 1966): Tidal Spectroscopy and Prediction. By W. H. Munk and D. E. Cartwright. Pp. 533-581. 188.; 2.70 dollars. No. 1106 , Vol. 259 (19 May 1966$)$ : On the Praseodymium +
Oxygen System. By B. G. Hyde, D. J. M. Bevan and L. Eyring. Pp. Oxygen System. By B. G. Hyde, D. J. M. Bevan and L. Eyring. Pp.
$583-614$ + plate 11. 138. 6d.; 2 dollars. (London: The Royal Society, 1966.)

Building Research Station Digest (Second Series) No. 70: Painting Metals in Buildings-1: Iron and Steel. Pp. 8. (London: H.M. Stationery Office, 1966.) $4 d$.

Northern Ireland: Ministry of Agriculture. Leaflet No. 103: Catch Crops Mp. 4. Leaflet No. 114: Foul Brood Distry of Agriculture, 1966.)
[205 BBC Lunch-time Lectures Fourth Series-7: English by Radio ar Television. By Christopher Dilke. Pp. 15. (London: British Broadeasting Corporation, 1966. Urgent Need for Medical Research. Pp. 9. (London: The
Migraine Trugt, 1966.)
[205

Problems with Solutions: a Chemical View of High-Temperature Materials. By Prof. C. B. Alcock. (Inaugural Lecture, 19 October 1965.) Pp. 165-189. (London: The Imperial College of Science and Technology, 1966.) 5s. [205 Ministry of Technology. Report of the National Physical Laboratory for
the year 1965 . Pp. xvi $+300+13$ plates. (London: H.M. Stationery the year 1965. Pp. xvi $+300+13$ plates. (London: H.M. Stationery
Office, 1966.) 20s. net.

Ministry of Technology. Electronic Automation in Britain, 1966. Pp.
42. (London: Ministry of Techno 42. (London: Ministry of Technology, 1966.)
University of Oxford. Annual Reports, 1964-1965. Pp. 32. (Supplement University of Oxford. Annual Reports, 1964-1965. Pp. 32. (Supplement
No. 7 to the University Gazette, Vol. 96, April 1966.) (Oxford: The Unj. versity, 1966.) $2 s .6 d$.
The British Leather Manufacturers Research Association. Annual The British Leather Manufacturers Research As8ociation. Annual
Report 1964-65. Pp. 71. (Figham, Surrey: The British Leather ManufacA Survey of the Major Indexing and Abstracting Services for Library Solence and Documentation. By H. Allan Whatley. Pp. 78. 288. (L. A. members 21s.) Classification Practice in Britain: Report on a Survey of Classification Opinion and Practice in Great Britain, with particular reference to the Dewey Decimal Classiflcation. By Keith Davison, Pp. 34.128. Office of Health Economics. Women in Medicine. (The results of an

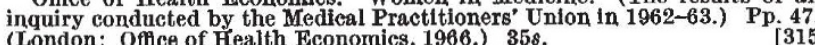

\section{Other Countries}

Institut Royal Météorologique de Belgique. Bulletin Trimestriel. Observations d'Ozone, 3e Trimestre, 1965. Pp. 36. (Uccle-Bruxelles: Institut
[255 [255
Pubblícazioni della Universitá degli Studi di Firenze: Facolta di Scienze Matematiche, Fisiche e Naturali. Osservazioni e Memorie dell Osservatorio Astroflisico di Arcetri. Fascicole 81: Catalogo delle Surges Solari Sul Diseo 1964. By Giovanni Godoli, Fabrizio Mazzucconi and Giancarlo Noci. Pp. 130. (Firenze: Universita degli Studi di Firenze, 1966.)

United States Department of Agriculture. Farmers Bulletin No. 2148: Aphids on Leafy Vegetables: How to Control Them. By W. J. Reid, Jr., Office, 1966.) 10 cents.

[315 tion. Annual Report of the Division of Applied Physics, 1964-65. Pp. 40. (Sydney: Commonwealth Scientific and Industrial Research Organization, 1965.) National Academy of Sciences-National Research Council. Publication 1292-D: Theoretical Chemistry-a Current Review. Pp. 44. (Washington, D.C.: National Academy of Sciences-National Research Councli, 1966.) 2 dollars. Proceedings of the United States National Museum, Smithsonian Insti-
tution. Vol.118, No. 3524: Copepod Crustaceans Parasitic on Flasmobranch Fishes of the Hawalian Islands. By Alan G. Lewis. Pp. 57-154. Vol. 118, No. 3524: Revision of the Pilargidae (Annelida: Polychaeta), Including Chamberlin (Polynoidae). By Marian H. Pettibone. Pp. 155-207. Vol. 118, No. 3529: A Review of the Beetles of the Genus Neobrotica and some Closely Related Genera. By Doris H. Blake. Pp. 267-371. (Washington, D.C.: Government Printing Offlce, 1966.) Deltatheridia, a New Order of Mammals. By Leigh Van Valen. Pp. 1-126+
plates 1-8. (New York: American Museum of Natural History, 1966.) plates 1-8. (New York: American Museum of Natural History, 1966.)
5 dollars. The American Philosophical Society. Year Book 1965. Pp. 786. (Philadelphia: The American Philosophical Society, 1966.) France a là Conférence des Nations Unies sur l'Application de la Sclence et de la Technique dans l'Intérèt des Régions peu Développées, Genève, 1963.) Pp. 466. (Paris: La Documentation Française, 16, rue Lord-Byron, United States Department of the Interior: Geological Survey. Professional Paper 440-W: Data of Geochemistry. Sixth edition. Chapter W: Chemistry of the Iron-rich Sedimentary Rocks. By Harold L. James. Pp.
iv +61 . 45 cents. Professional Paper 503-F: The Lower Cretaceous (Albian) Ammonito Genera Leconteites and Brewericeras. By David L. Jones, Michael A. Murphy and Earl L. Packard. Pp. iil + 21 + plates 1-11. 50 cents. Professional Paper 504-F: Underground Temperatures and Heat Flow in the East Tintic District, Utah. By T. S. Lovering and $\mathbf{H}$. T. Morris. Pp. iii + $28+$ plates $1-5$. Professional Paper 526-B: Stratigraphy of Madison Group near Livingston, Montana, and Discussion of Karst and Solution-Breccia 537-C: An Acid Fumarolic Gas from Kilauea Iki, Hawaii. By K. J. Murata. (The 1959-60 Eruption of Kilauea Volcano, Hawail.) Pp. iil +6. . 15 cents. (Washington, D.C.: Government Printing Office, 1965 and 1966.) [315 Astronomical Papers prepared for the use of the American Ephemeris and
Nautical Almanac. Vol. 18: Expansions in Elliptic Motion. By Milton P. Jarnagin, Jr. Pp. xxxvi + 659. (Washlngton, D.C.: Government Printing

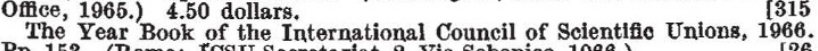
Pp. 153. (Rome: ICSU Secretariat, 2, Via Sebenico, 1966.) Smithsonian Miscellaneous Collections. Vol. 151, No. 4: Parapercis
Kamoharai (Family Mugilooldidae), a New Fish from Japan with Notes on Kamoharai (Family Mugiloldidae), a New Fish from Japan with Notes on
Other Species of the Genus. By Leonard P. Schultz. Pp. 4+1 plate. (PubOther Species of the Genus. By Leonard P. Schultz. Pp. 4+1 plate. (Pub-
lication 4669.) (Washington, D.C.: Smithsonian Institution, 1966.) [26 Survey of Canada. Memoir No 336: Flathead Map-Area, British Columbia and Alberta. By R. A. Price. Pp. 221 (11 plates). 6 dollars. Paper 65-17: Age Determinations and Geological Studies-K-Ar Isotopic Ages, Report 6, By R. K. Wanless, R. D. Stevens, G. R. Lachance and J. Y. H. Rimsaite. Pp. vi +101 . 75 cents. Paper 65-24: Superficial Geology of Duncan and 75 cents. Paper 66-9: Machine Methods as Aids in the Preparation of Geophysical Maps. By B. K. Bhattacharyya and D. N. Clay. Pp. v+18. 75 cents. (Ottawa: Queen's Printer, 1965 and 1966.)
[26 Board of Grain Commlssioners for Canada, Winnipeg. Grain Research
Laboratory 1965 Report. Pp. v +83 . (Ottawa: Queen's Printer, 1966.) [26
Canada: Department of Mines and Technical Surveys. Annual Report Canada: Department of Mines and Technical Surveys. Annual Report
for the Calendar Year 1964. Pp. 54 + 14 photographs. (Ottawa: Queen's Printer, 1965.)
United States Department of Commerce: National Bureau of Standards. United States Department of Commerce: National Bureau of Standards.
Technical Note 18-25: Quarterly Radio Noise Data, December, January, Technical Note 18-25: Quarterly Radio Noise Data, December, January,
February 1964-65. By W. Q. Crichlow, R. T. Disney and M. A. Jenkins. Pp. vi +52. (Washington, D.C.: Government Printing Office, 1966.) 40 cents.
India: Council of Scientifle and Industrial Research. Proceedings of the India: Council of Scientifle and Industrial Research. Proceedings of the tory, Council of Selentific and Industrial Research, 1966.)

\footnotetext{
Editorial and Publishing Offices of "NATURE"

MACMILLAN (JOURNALS) LIMITED

4 LITTLE ESSEX STREET, LONDON, W.C.2.

Telephone Number: Temple Bar 6633. Telegrams: Phusis London W.C.2.

Annual subscription: Inland $£ 14$, Overseas $£ \mid 3$ I5s., payable

in advance, postage paid to any part of the world.

Advertisements only should be addressed to

T. G. Scott \& Son, Ltd, I Clement's Inn, London, W.C.2 Telephone Number: Holborn 4743

Registered as a newspaper at the General Post Office

Copyright (C) Macmillan (Journals) Limited, July 23, 1966
} 